REVISTA de PEDAGOGIE
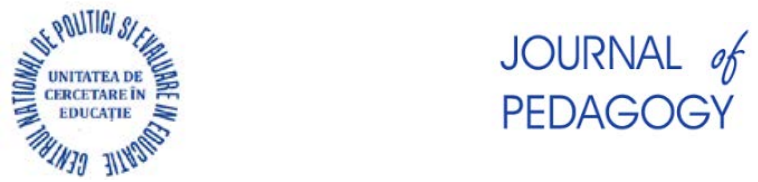

http://revped.ise.ro

Print ISSN 0034-8678; Online ISSN: 2559 - 639X

\title{
TEACHING EXPERIENCES IN THE DEVELOPMENT OF THE COMMUNICATION COMPETENCE IN STUDENTS WITH COGNITIVE DISABILITY
}

Experiențe didactice în formarea competenţei de comunicare a elevilor cu dizabilități intelectuale

\section{Mădălina-Maria VASILIU}

Journal of Pedagogy, 2020 (2), 181 - 201

https://doi.org/10.26755/RevPed/2020.2/181

The online version of this article can be found at: http://revped.ise.ro/en/2020/

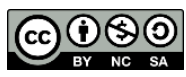

This work is licensed under the Creative Commons Attribution-NonCommercial-ShareAlike 4.0 International License.

To view a copy of this license, visit http://creativecommons.org/licenses/by-nc-sa/4.0/ or send a letter to Creative Commons, PO Box 1866, Mountain View, CA 94042, USA.

Published by:

Centrul Național de Politici și Evaluare în Educație

UNitATEA DE CERCETARE ÎN EDUCAȚIE

http://www.ise.ro/

https://rocnee.eu/

Further information about Revista de Pedagogie - Journal of Pedagogy can be found at:

Editorial Policy: http://revped.ise.ro/editorial-policy/

Author Guidelines: http://revped.ise.ro/en/author-guidelines/ 


\title{
EXPERIEN E DIDACTICE ÎN FORMAREA COMPETEN EI DE COMUNICARE A ELEVILOR CU DIZABILITĂ I INTELECTUALE
}

\section{Mădălina-Maria Vasiliu*}

\author{
Colegiul „Mihai Viteazul” Ineu, \\ Ineu, România \\ vasiliumadalina92@yahoo.com
}

\section{Rezumat}

Analiza de fa ă pleacă de la constatarea că profesorul care se adresează elevilor cu dizabilită i intelectuale întâmpină o multitudine de provocări în gestiunea învă ării, din cauza limitelor copiilor de a desfăşura diferite activită i (generalizare, abstractizare sau opera ii inductiv-deductive), şi este pus în situa ia de a alege activită i eficiente pentru dobândirea competen elor vizate. În acest context, nu poate fi vorba de reuşită fără o reală raportare la nevoile de învă are ale fiecărui elev şi în afara unei rela ii afective, de încredere, construită între profesor şi elev, alături de părin i. Dezvoltarea competen ei de comunicare este o necesitate, doar în acest fel elevii deficien i se pot integra în societate, îşi pot exprima sentimentele, nevoile şi părerile. Provocarea de a proiecta strategii didactice adecvate este corelată cu în elegerea problemei reale a copilului şi rezolvarea la timp a acesteia: cu cât dizabilitatea intelectuală a unui elev este mai mare, cu atât limbajul său se dezvoltă mai târziu şi rămâne la un nivel mai scăzut la vârsta adultă, ducând la dificultă i în exprimarea gândurilor şi a emo iilor. Indiferent dacă este vorba de o pseudodizabilitate, declanşată de lipsa stimulării educative a elevilor, ori de o dizabilitate intelectuală autentică, aceşti elevi au nevoie de sprijin sus inut. Exemplele de interven ii prezentate în articolul de fa ă sunt rezultatul încercărilor noastre de a valorifica cât mai bine poten ialul intelectual al acestor copii şi, implicit, de a găsi solu ii pentru adaptarea diferen iată la nevoile tuturor copiilor, prin proiectarea unor activită i didactice creative, axate pe competen e.

* Profesor de limba şi literatura română, Colegiul ,,Mihai Viteazul” Ineu, jude ul Arad, România. 
Cuvinte-cheie: competen e de comunicare, (pseudo)dizabilită i intelectuale, strategii de învă are adaptate.

\begin{abstract}
The current analysis starts from a teacher's experience with cognitively disabled students. In such cases, the management of the teaching-learning process is challenged by the limitations of various activities (generalizations, abstraction or inductive-deductive operations). In these situations, the teacher has to select effective activities for developing the competences in the curriculum. In this context, success could only be obtained if proper attention is given to the individual learning needs of each student. At the same time, an emotional relationship, that is based on trust needs to be developed between the teacher and the students and their parents. The communication competence is a priority since it is absolutely necessary for the social integration of students with disabilities as it provides the means to express feelings, needs and views. The challenge to plan adequate teaching strategies is correlated with understanding the child's real issue and its timely solution: the more serious the cognitive disability, the later speech develops and remains at a low level in the adult life, generating difficulties in expressing thought and emotion. If the youngsters experience a false disability triggered by the lack of educational stimulation or if they have an authentic cognitive disability, these students need sustained support. The examples of interventions we present in this paper come from our attempts to best value the intellectual potential of these children and, consequently, to find solutions for a differentiated adaptation to each child's needs by planning competence-oriented creative teaching activities.
\end{abstract}

Keywords: adapted teaching strategies, communication competences, (false) cognitive disability. 


\section{Context general}

Se spune că a fi profesor nu e o meserie, e o voca ie, înseamnă să dăruieşti o părticică din tine copilului ce stă în fa a ta. Copiii aşteaptă să primească „bucă i de via ă”: cunoştin e, abilită i şi atitudini. Fiecare copil e diferit. Unii copii sunt mereu veseli şi optimişti, al ii sunt melancolici şi visători, unii puternici, al ii mai slabi, unii sunt înzestra i intelectual, al ii au anumite deficien e. Indiferent de toate acestea, profesorul trebuie să-i dăruiască copilului competen e, să îl sprijine în procesul său de dezvoltare. Şi oare nu e mai înăl ător pentru un profesor să ofere ,,bucă i de via ă” elevilor slabi, neajutora i, pierdu i şi cu deficien e, elevilor care nu au şi poate aşteaptă să primească? Tocmai din această cauză, profesorul trebuie să privească drept o provocare să aibă în clasa sa un elev cu dizabilită i intelectuale. Trebuie să studieze caracteristicile acestor copii pentru a-i putea sprijini în activitatea lor, să înve e să se autodepăşească şi să îşi adapteze întreg procesul educa ional la nevoile lor.

În cadrul acestui articol, pentru a în elege elevul cu cerin e educa ionale speciale, am avut în vedere precizările privind clasificarea interna ională a func ionării, dizabilită ii şi sănătă ii (OMS, 2004) în care se precizează că „Dizabilitatea este produsă de interac iunea dintre trăsăturile de sănătate şi factorii contextuali. Aşa stând lucrurile, indivizii nu trebuie să fie reduşi la, sau caracteriza i exclusiv din perspectiva afec iunilor, limitărilor în activitate sau restric iilor în participare cu care se confruntă. De exemplu, în loc să folosească termenul de ,persoană handicapată mintal”, clasificarea utilizează expresia ,persoană cu o problemă de învă are” (p. 247). Am avut în vedere, de asemenea, aspecte privind copilul cu dizabilită i intelectuale, de învă are, şi solu ii pe care le-am identificat pe parcursul orelor de limbă şi literatură română, în contextul noului curriculum bazat pe competen e, la nivelul gimnaziului.

În spa iul educa ional apar frecvent discu ii generate de întrebări legate de problematica competen elor: ce înseamnă, ce tipuri de competen e sunt necesare pentru a forma o persoană autonomă, cum pot fi formula i descriptorii de nivel pentru a realiza un profil al elevului etc. Competen a se dobândeşte prin învă are, în eleasă ca activitate intelectuală şi fizică derulată într-un cadru formal sau informal, în mod spontan sau organizat, prin care o 
persoană dobândeşte cunoştin e, abilită i şi atitudini necesare dezvoltării continue a propriului poten ial. Educa ia actuală este organizată în jurul a patru elemente fundamentale de învă are, care, pe parcursul vie ii, constituie pilonii cunoaşterii: $a$ învă a să ştii, ceea ce înseamnă dobândirea instrumentelor cunoaşterii, a învă a să faci, formarea unor abilită i, astfel încât individul să intre în contact cu mediul înconjurător, a învă a să fii, respectiv, însuşirea unui set de valori şi atitudini. Putem spune că educa ia s-a concentrat, până la apari ia noii reforme curriculare, pe a învă a să ştii şi, într-o mică măsură pe a învă a să faci. Componenta referitoare la $a$ invă a să fii pare să fi fost lăsată la voia întâmplării sau se presupune că rezultă în mod natural din primele două. Prin urmare, competen a înseamnă atât cunoştin e şi abilită i, cât şi atitudini. Pentru a fi competentă, o persoană trebuie să de ină cunoştin e, date şi informa ii din domeniul în care activează şi chiar din mai multe domenii, să îşi pună în practică cunoştin ele dobândite, formându-şi astfel abilită ile necesare profesării unei meserii, ca prin intermediul atitudinilor, a setului de valori şi principii personale, să poată să îşi câştige respectul semenilor şi să îşi practice meseria cu demnitate. Competen a reprezintă ,un poten ial cognitiv, opera ional, afectiv-atitudinal care se manifestă cu succes atunci când situa ia o cere" (Mircea, 2006, p. 57).

În educarea elevilor cu dizabilită i intelectuale, profesorul trebuie să pornească de la componenta atitudinală, de la ,a învă a să fiii”. Aceşti elevi au nevoie să se descopere, să capete încredere în propriile puteri, să îşi creeze o atitudine pozitivă fa ă de învă are. Ac iunile de predare ale profesorului, cât şi ac iunile de învă are ale elevilor cu dizabilită i intelectuale sunt influen ate de moralul grupului, ca şi de natura rela iilor cu ceilal i membri ai grupului. De aceea, interac iunea într-un context afectiv devine determinantă pentru elevii vulnerabili. Pentru că are nevoie de un mediu în care să se simtă acceptat, în care să se poată manifesta liber în încercarea de a deveni independent, copilul cu dizabilitate intelectuală trebuie încurajat, atmosfera din clasă trebuie să fie primitoare.

Din cauza dificultă ilor întâmpinate în însuşirea materialului şcolar, elevii cu dizabilită i intelectuale nu au interese adânci şi de durată pentru activitatea intelectuală. Sub influen a adul ilor, aceştia pot dobândi anumite judecă i apreciative cu privire la importan a învă ăturii, a absolvirii şcolii, însă acestea nu sunt interiorizate şi nu au caracter mobilizator. Interesele de cunoaştere 
ale elevilor cu dizabilită i intelectuale sunt mult mai scăzute decât ale celorlal i elevi. Printr-o educa ie corectă şi sus inută li se poate trezi interesul pentru anumite aspecte ale activită ii şcolare. În această situa ie, este de dorit ca ac iunea educativă să vizeze stimularea nevoilor profunde ca, de pildă, dorin a copilului de a progresa şi de a avea experien e noi, nevoile sale de crea ie, de expresie şi de rela ii sociale. Această atitudine conduce în chip firesc către o pedagogie axată pe persoană şi pe interesele sale.

În plan educativ, şcolar, elevii cu dizabilită i intelectuale au nevoie de o educa ie specială, adaptată cerin elor speciale de învă are. De aceea, în cadrul şcolar se foloseşte sintagma elev cu CES, respectiv elev cu nevoi/ cerin e educative speciale. Integrarea acestor elevi cu diferite dificultă i de învă are într-o şcoală obişnuită este un beneficiu, deoarece aceştia au şansa de a interac iona cu ceilal i elevi, participând la activită i educative variate, integrându-se în societate. Şcoala incluzivă este şcoala tuturor, dreptul la educa ie este al oricărui copil. O şcoală incluzivă se ocupă de educa ia tuturor copiilor unei comunită i, indiferent de mediul de provenien ă al acestora, de capacită ile lor intelectuale sau de deficien ă. Şcoala obişnuită este una incluzivă atunci când acceptă diversitatea. Acceptarea diferen elor, empatia, incluziunea, sprijinul necondi ionat, egalitatea de şanse sunt deziderate ale educa iei moderne.

\subsection{Rolul curiozită ii în învă are}

Pentru ca elevii să continue să manifeste interes pentru o problemă, trebuie să le fie moblizată curiozitatea, în felul acesta, ei vor consim i să facă eforturile necesare pentru lămurirea tuturor aspectelor nou întâlnite. Fiin a umană percepe ceea ce o interesează şi ceea ce caută. Procesul educa ional este eficient dacă elevul are interesul şi nevoia de a şti, de a face experien e personale şi de a progresa. În primă instan ă, interesul elevilor este stimulat cu predilec ie de lec iile în care se introduce elementul ludic, jocul. Ulterior, elevii cu dizabilită i intelectuale ajung să se simtă confortabil, devin activi şi implica i. Totuşi, aceştia trebuie să ajungă să în eleagă şi valoarea educativă a jocului, ceea ce implică asumarea răspunderii, respectarea regulilor jocului, canalizarea efortului şi a aten iei. Privind activitatea educativă ca un joc pe care îl poate câştiga, elevul cu dizabilită i intelectuale se mobilizează şi poate ob ine rezultatele aşteptate de profesor şi de el însuşi. Un rol important în 
trezirea şi men inerea interesului de cunoaştere îl are legarea cunoştin elor teoretice de experien a de via ă a elevilor, deoarece ei sunt capabili să surprindă legătura dintre cunoştin ele teoretice şi activitatea practică.

\subsection{Rolul dialogului în învă are}

Elevul cu dizabilită i intelectuale este adesea incapabil să extragă idei dintro situa ie concretă şi, tocmai aici, dialogul cu profesorul favorizează acest proces de generalizare a no iunilor. Comunicarea didactică are mai multe caracteristici, care o deosebesc de comunicarea interumană din situa ii cotidiene de via ă. Aceasta presupune o interac iune cooperantă între educator şi educabil, este preocupată de ceea ce se transmite şi de cum se transmite. Comunicarea în situa ie didactică urmăreşte un scop educativ, îndreptat către formarea unor competen e văzute ca ansambluri de cunoştin e, abilită i şi atitudini ale elevilor. Pentru atingerea acestui scop, este nevoie să se stabilească o interac iune care să favorizeze activită ile desfăşurate de elevi în cooperare cu profesorul, adică să se caute un mod de se crea o coeziune de grup şi un parteneriat real între profesor şi elevi.

Pentru a stabili în clasă un dialog autentic, profesorul trebuie să creeze situa ii semnificative de învă are, ceea ce presupune, pe lângă multe altele, să manifeste şi el însuşi disponibilitatea de a învă a de la elev.

Empatia constituie, de asemenea, o calitate importantă pe care trebuie să o aibă un profesor. Elevul care primeşte răspuns la o întrebare ce-l interesează înva ă mult mai bine decât atunci când i se predă, lui revenindu-i un rol pasiv. Un dialog autentic nu poate fi redus la întrebări limitate din partea profesorului şi la răspunsuri scurte date de un elev sau altul. El presupune ca profesorul să accepte întrebările elevilor şi, mai mult, să îi încurajeze să gândească, să caute răspunsuri la propriile nelămuriri şi să pună întrebări pentru clarificare sau pentru satisfacerea unor curiozită i. Elevului trebuie, aşadar, să i se lase acest spa iu de interven ie şi să înve e să îşi pună întrebări.

Aşadar, comunicarea şcolară, dialogul autentic dintre profesor şi elev, trebuie să fie axată pe procesul de învă are al elevilor şi pe dezvoltarea personalită ii lor. În cazul elevului cu dizabilită i intelectuale sau a elevului cu cerin e 
educa ionale speciale, profesorul întâmpină mai multe dificultă i în dezvoltarea unui dialog autentic şi în realizarea activită ilor didactice, deoarece copiii nu pot face acest lucru, nu au capacitatea de a desfăşura anumite activită i de bază, în special, activită i de generalizare, abstractizare sau opera ii inductivdeductive.

\subsection{Rolul părin ilor/ parteneriatul cu părin ii}

Randamentul scăzut al copiilor poate fi cauzat atât de deficien a intelectuală, cât şi de insuficienta stimulare educativă din partea părin ilor. În cea de-a doua situa ie, neimplicarea părin ilor în educa ia copiilor poate produce tulburări în sfera afectivă, care să blocheze dezvoltarea intelectuală, ducând la pseudodizabilitate intelectuală. Cu cât caren ele afective sunt mai mari, cu atât intelectul copilului e mai scăzut. Pseudodizabilitatea intelectuală se deosebeşte greu de autentica dizabilitate intelectuală. De exemplu, un copil dintr-o famile dezorganizată, instabil emo ional, cu probleme de ataşament, poate să aibă dificultă i de comunicare, care derivă din frica copilului de a greşi, de a fi judecat, certat, pedepsit. De aceea, părin ii au un rol fundamental în dezvoltarea intelectului copiilor lor. Având în vedere aceste aspecte, ne dăm seama cât e de dificil să ne raportăm la un diagnostic privind dizabilită ile intelectuale ale copilului pentru construirea unor strategii de învă are eficiente. Aten ia şi creativitatea copiilor trebuie stimulate începând cu primele luni din via ă şi se bazează pe comunicare. Părin ii trebuie să le vorbească copiilor, să le dezvăluie lumea înconjurătoare pentru ca aceştia să se poate integra ulterior în societate.

Comunicarea dintre părinte şi copil necesită doar resurse de timp, pu ină disponibilitate şi creativitate din partea părintelui. Copilul are nevoie de timp, timp să i se vorbească, timp să i se citească, să i se prezinte obiecte, imagini, culori şi forme, timp să i se arate afec iunea. În acest mod, copilului i se dezvoltă afectivitatea, aten ia, înva ă să aibă răbdare, să asculte. În secolul vitezei, în era tehnologiei, în care lumea e în continuă mişcare şi schimbare, copilul trebuie învă at să aştepte. Am observat că operând la nivelul sferei afective, stimulând aten ia şi răbdarea, copilul are şanse mari să se dezvolte intelectual corespunzător. 


\subsection{Rolul lecturii}

Timpul petrecut de părinte citindu-i copilului e unul în care se creează o legătură puternică de ataşament, e o situa ie de comunicare învăluită în duioşie. Astfel, copilul asociază cartea cu acel moment special în care mama sau tata îl ine în bra e şi îi citeşte, ajungând cu timpul să iubească lectura, reuşind să citească singur şi să înve e pe tot parcursul vie ii.

Competen a de comunicare în limba maternă se dobândeşte aşadar treptat, începând cu primul an de via ă al persoanei, câştigând permanent mai multă autonomie, până la maturitate, şi devenind astfel capabilă să participe la diverse situa ii de comunicare şi să îşi exprime opiniile.

Roman Jakobson în studiul „Lingvistică şi poetică” (1964) elaborează o schemă a comunicării, inspirată din modelul tehnic al telecomunica iilor, care cuprinde şase factori: emi ătorul, receptorul, codul, mesajul, canalul, contextul. Emi ătorul sau vorbitorul concepe, organizează, structurează logic mesajul (informa ia, ideea) şi o emite folosindu-se de un cod, respectiv de un sistem de semne, ce poate fi lingvistic (limba), gesturile, semnalele vizuale, sonore, coduri artistice (plastic, muzical, cinematografic), codul Morse, sistemul Braille etc. Transmiterea mesajului se realizează printr-un canal (vizual, auditiv, chinestezic, tactil, olfactiv). Receptorul (ascultătorul, spectatorul, cititorul) receptează mesajul, ̂ll prelucrează şi astfel reuşeşte să-l decodifice. În acelaşi context al comunicării, Borchin (2005) consideră că „,Receptarea este actul de interiorizare a unui mesaj, care se desfăşoară, de asemenea, în mai multe etape: de la manifestarea desponibilită ii de a primi mesajul, la perceperea şi apoi interpretarea acestuia" (p. 35).

Codul trebuie să fie cunoscut atât de emi ător, cât şi de receptor. După decodificare, receptorul preia rolul de emi ător şi oferă feedbackul său în legătură cu informa ia primită. Transmiterea mesajului se realizează într-un context, care constituie circumstan ele comunicării: timpul şi spa iul în care are loc, participan ii, lumea la care face referin ă mesajul. Referentul poate fi real (lumea înconjurătoare, realitatea) sau fictiv (în operele literare, cinematografie). 


\subsection{Dezvoltarea limbajului}

Posibilită ile individului de a face fa ă cerin elor se ameliorează când i se oferă condi ii educative şi o via ă adecvată, observa ie valabilă şi în cazul dezvoltării limbajului. În urma activită ii mele de pedagog, am observat că un copil care stă mult timp în prezen a adul ilor, mai ales dacă aceştia îl stimulează să vorbească, îşi va dezvolta mai repede limbajul decât un altul care îşi petrece aproape tot timpul cu copii de o vârstă apropiată.

Întârzierile în dezvoltarea limbajului pot fi semne ale dizabilită ii intelectuale ale unui copil, putându-se stabili corela ii între întârziere şi gravitatea deficien ei. Acelaşi fenomen de întârziere a apari iei limbajului poate apărea atât din cauza unor boli sau deficien e organice, cât şi din cauza insuficientei stimulări verbale în mediul de via ă al copilului sau chiar din cauza unui şoc afectiv puternic. Pot fi amintite cazurile unor copii care au început să vorbească după trei ani, iar mărturisirile lor privind această întârziere sunt valoroase (de exemplu, experien a poetului Lucian Blaga povestită în Hronicul şi cântecul vârstelor, 2012). S-a observat că nu există la copiii cu dizabilită i intelectuale tulburări ale limbajului specifice, toate deficien ele constatate la această categorie de copii putând fi întâlnite şi la ceilal i copii. Copiii normal dezvolta i reuşesc să îsi însuşească limbajul în timp, îşi remediază prin exerci iu deficien ele vorbirii, fără a fi nevoie de o activitate corectivă specială, ca în cazul copiilor cu probleme de dezvoltare: „La deficien ii mintali limbajul se dezvoltă, în general, cu întârziere, sub toate aspectele sale" (Roşca, 1967, p. 113).

Încă din cele mai vechi timpuri, oamenii au acordat o importan ă deosebită con inutului şi formei exprimării, deoarece prin intermediul limbajului se pot face cunoscute gândurile, ideile, sentimentele. Limbajul reprezintă totalitatea modurilor de comunicare. Fenomen complex, limbajul reuneşte trăsături de diverse naturi: fizice, fiziologice, psihice, logice, sociale şi, nu în ultimul rând, particularită i individuale. „Studiile anatomice au demonstrat că pentru realizarea laturii de expresie a limbajului sunt puse în mişcare diferite organe, sisteme şi aparate cu func ii specifice; sistemul respirator, auditiv, dispozitivul fonator, aparatul articulator etc. sunt orchestrate de creierul uman în activitatea de producere de semne şi de combinare a semnelor în structuri, de antrenare a acestora în rela ii sistematice" (Borchin, 2005, p. 31). Orice problemă de 
la nivelul acestor sisteme şi aparate poate crea tulburări, handicapuri de limbaj. De aceea, dezvoltarea limbajului cât şi eventualele sale deteriorări trebuie urmărite cu aten ie, în cadrul evolu iei întregului sistem psihic uman. „Rămânerea în urmă a copiilor deficien i mintali apare în mod şi mai evident atunci când se ia în considerare etatea la care vorbirea începe să se desfăşoare sub formă de propozi ii. La normali acest mod de comunicare se observă la 1,7 ani, iar la deficien i mintali abia la 3 ani" (Roşca, 1967, p. 112). Dacă la un copil pronun area primului cuvânt apare cu întârziere, dar la un scurt interval se trece la propozi ii, trebuie exlusă ipoteza că ar fi vorba de un copil cu dizabilită i intelectuale. „,Deficien ele limbajului se manifestă la copiii cu deficien ă mintală sub variate aspecte: al percep iei şi în elegerii vorbirii interlocutorului, al volumului vocabularului şi al complexită ii frazelor utilizate, al expresivită ii vorbirii, al articulării, fona iei şi ritmului vorbirii, al mijloacelor auxiliare de comunicare etc." (Roşca, 1967, p. 115).

\section{Strategii didactice utilizate la clasă}

Strategiile didactice propuse sunt dedicate elevilor cu dizabilită i intelectuale din ciclul gimnazial, integra i în învă ământul obişnuit. Selectarea în mod adecvat a strategiilor didactice pentru formarea competen elor de comunicare în situa ia elevilor cu dizabilită i intelectuale îl pune pe profesor în situa ia de a lua în considerare particularită ile specifice elevului cu dizabilită i intelectuale. Strategia didactică descrie modul în care elevul este pus în contact cu con inuturile de învă are, aceasta conferă solu ii cu privire la proiectarea şi combinarea diferitelor metode, mijloace, forme şi resurse de predare-învă are, pentru ca elevii să ajungă la achizi iile dorite, iar obiectivele educa ionale să fie atinse.

Rezolvarea tulburărilor afective, utilizarea instruirii programate, a muncii organizate, îmbinarea eficientă a activită ilor frontale cu cele individuale şi chiar în echipă sunt cerin e de bază în educarea copiilor cu dizabilită i intelectuale. Deoarece limbajul este un fenomen complex, activitatea educativă de dezvoltare şi de corectare a acestuia trebuie să fie multilaterală. Punctul de plecare îl constituie dezvoltarea unei motiva ii adecvate. $\mathrm{Cu}$ alte cuvinte, este necesar, în primul rând, să se ob ină cooperarea copilului, să i se trezească interesul pentru activitatea de comunicare prin limbaj şi dorin a 
de a vorbi corect. În al doilea rând, activitatea educativă nu se poate reduce la corectarea articulării, a ritmului şi a fona iei. Trebuie să se urmărească dezvoltarea limbajului ca instrument al gândirii şi ca mijloc de reglare a activită ii. Gândirea elevului se dezvoltă odată cu limbajul, de aceea profesorul trebuie să îmbogă ească bagajul de reprezentări al elevilor, stimulând activitatea de reflec ie. Exerci iile de vorbire nu trebuie să aibă caracter formal, nu se vor reduce la repetarea, mai mult sau mai pu in corectă, a unor cuvinte, ci se vor axa pe exprimarea unor impresii şi idei personale. Exprimarea impresiilor şi ideilor personale este o provocare chiar şi pentru elevii normal dezvolta i, cu atât mai mult pentru elevii deficien i. Profesorul nu trebuie să neglijeze activită ile care pun în valoare formularea unor răspunsuri personale şi creative pe marginea unor texte de diferite tipuri. Textele abordate trebuie însă să abordeze teme familiare şi să aibă un nivel scăzut de dificultate.

În vederea dezvoltării competen ei de a exprima idei, opinii, păreri personale cu privire la anumite texte studiate, profesorul poate utiliza la orele de lectură jurnalul cu dublă intrare. Această metodă le oferă elevilor libertatea de a comenta, de a face aprecieri cu privire la anumite secven e din textele literare studiate la clasă. De exemplu, după lectura unui fragment din Micul prin , de Antoine de Saint-Exupery, elevii au fost provoca i să îşi exprime părerea în legătură cu următoarea secven ă din text: ,,Nu se vede bine decât cu inima. Esen ialul e invizibil pentru ochi”. Citatul presupune un grad destul de înalt de abstractizare, profesorul având sarcina de a-i sprijini pe elevi, prin întrebări ajutătoare, să în eleagă secretul dezvăluit de vulpe micului prin . Elevii au reuşit să enumere lucrurile care nu se văd cu ochii, de exemplu, prietenia, iubirea, respectul, sentimentele umane, dar se simt în inimă, descoperind că tocmai lucrurile care nu se văd dau valoare vie ii noastre. Vocabularul elevilor cu dizabilită i intelectuale este mai limitat decât cel al celorlal i copii, mai ales sub aspectul cuvintelor-no iuni, cu caracter abstract. Adeseori, aceste cuvinte sunt greşit utilizate într-un context diferit de acela în care ele au fost învă ate. De aceea, această activitate îi provoacă pe elevii cu dizabilită i intelectuale să gândească şi să îşi formeze capacitatea de abstractizare.

Elevii cu dizabilită i intelectuale nu au capacitatea de a în elege şi de a utiliza figurile de stil: compara iile, epitetele şi metaforele. În elegerea acestora implică un grad înalt de abstractizare. În schimb, aceştia au dezvoltat gustul 
artistic, pot aprecia un text artistic. Profesorul trebuie să îi familiarizeze pe elevi cu diferitele tipuri de texte: literare şi nonliterare, îmbogă indu-le astfel, permanent, vocabularul. În vocabularul copiilor cu dizabilită i intelectuale apar mai mult substantive, deoarece acestea denumesc lucruri sau fiin e ce pot fi uşor de asociat în realitate. Cu toate acestea, nici substantivele nu sunt utilizate întotdeauna corect. Numărul de verbe de care dispun aceşti copii pentru a exprima diferitele ac iunii este mult mai mic decât la celal i copii. La fel se întâmplă şi în situa ia adjectivelor, din această cauză limbajul elevilor cu dizabilită i intelectuale părând că este lipsit de expresivitate, de coloratură stilistică. Aceştia au dificultă i în a asocia substantivelor adjectivele adecvate. Pentru a oferi un suport activită ii de vorbire, am utilizat cât mai multe machete, obiecte, imagini, căr i, suporturi audio şi video. Copilul reuşeşte să îşi însuşească no iunile noi mult mai uşor dacă primeşte şi un stimul vizual, clar şi concret.

Via a modernă a adus cu sine o mare gamă de mijloace imagistice de comunicare: afişul, posterul, fotografia, ilustra iile sau chiar televiziunea şi cinematografia. Printre acestea, cartea ilustrată este o resursă educativă de o valoare incontestabilă. Ilustra ia stimulează aten ia şi imagina ia elevilor. Dacă textul scris este pentru cei care ştiu să citească, imaginea se adresează atât cititorilor aviza i, cât şi celor care nu ştiu să citească. Există căr i alcătuite exclusiv din imagini, care pot fi citite de fiecare dată altfel, descoperind de fiecare dată alte nuan e ale povestirii. De exemplu, câ iva elevi cu dizabilită i intelectuale au fost provoca i să descrie imaginile de mai jos, urmărind ac iunile personajelor. În acest fel se realizează o impregnare a copilului cu material verbal. În urma acestei activită i, elevii au învă at cuvinte noi, utilizând corect, adecvat şi eficient limba în procesul comunicării orale. 


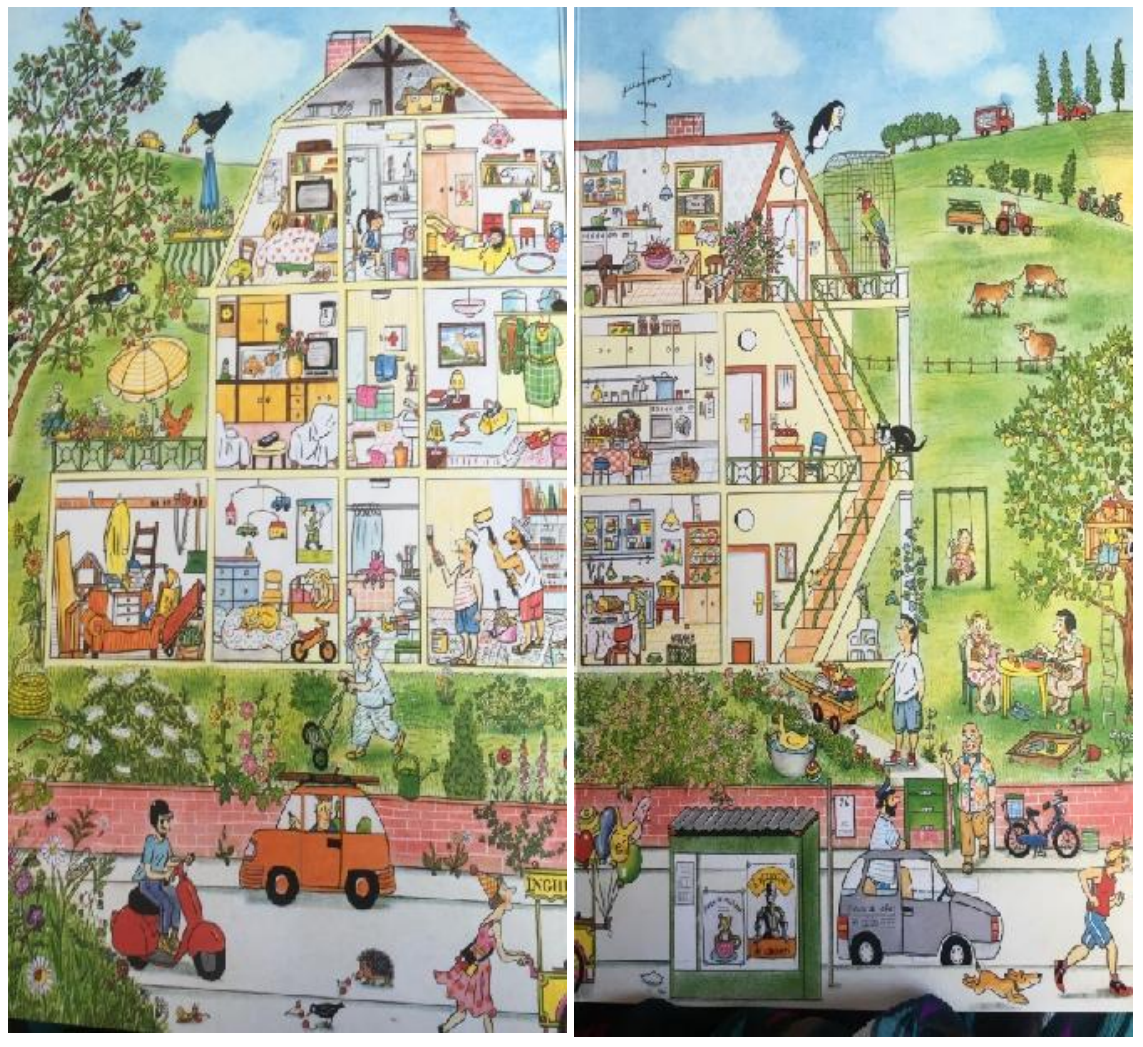

Figura nr. 1. Lectura unei imagini

Sursa: Hoinari prin anotimpuri, de Rotraut Susanne Berner, Editura Casa, Oradea 2018

Tot legat de lectura imaginii, am realizat şi o activitate de asociere a imaginii cu textul. De exemplu, pornind de la Cartea cu Apolodor, de Gellu Naum (2016), elevii au avut de asociat imaginile din coloana A cu versurile din coloana B. Asocierea imaginii cu textul a facilitat în elegerea nara iunii. 
A $\quad$ B

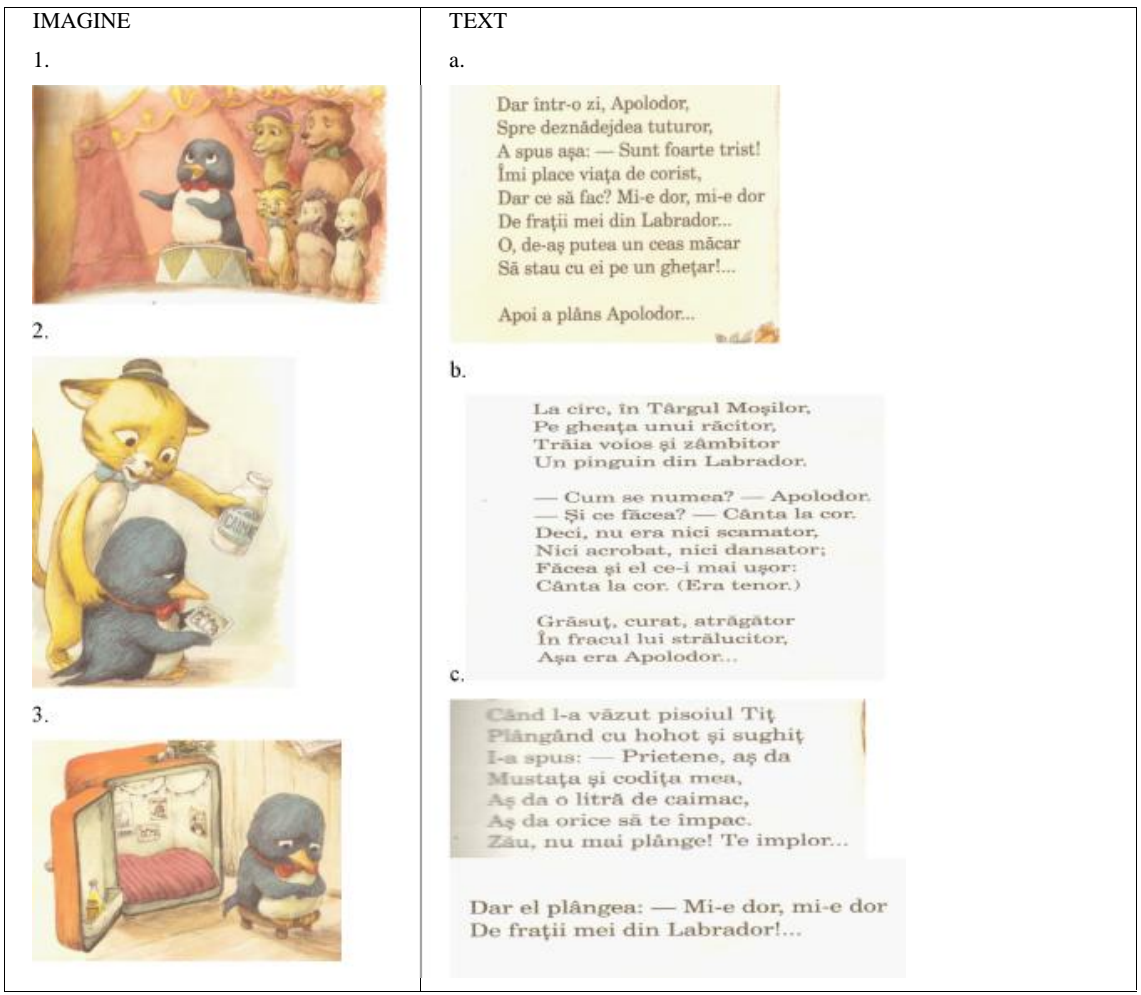

Figura nr. 2. Asocierea imaginii cu textul

Sursa: Cartea cu Apolodor, de Gellu Naum (2016)

În vederea formării competen ei de comunicare scrisă, respectiv de redactare, am folosit metoda cvintetului, deoarece am constatat că este îndrăgită de copii. Metoda constă în alcătuirea unei poezii pe baza unor sugestii privind fiecare vers. Următorul cvintet are în vedere textul Cartea cu Apolodor (Naum, 1988). Structura cvintetului trebuie să ină seama de imaginile prezentate şi de câteva reguli de redactare.

Primul vers este format dintr-un singur cuvânt, care să denumească personajul din imagine. Al doilea vers este format din două cuvinte, care definesc caracteristicile acestuia (două adjective). Al treilea vers este format din trei 
cuvinte, care exprimă ac iuni (de exemplu, verbe la infinitiv, indicativ prezent sau gerunziu). Al patrulea vers reprezintă o propozi ie care exprimă starea indusă elevului de respectiva imagine. Al cincilea vers este format dintr-un cuvânt care să prezinte însuşirea ilustrată de imaginea în cauză.

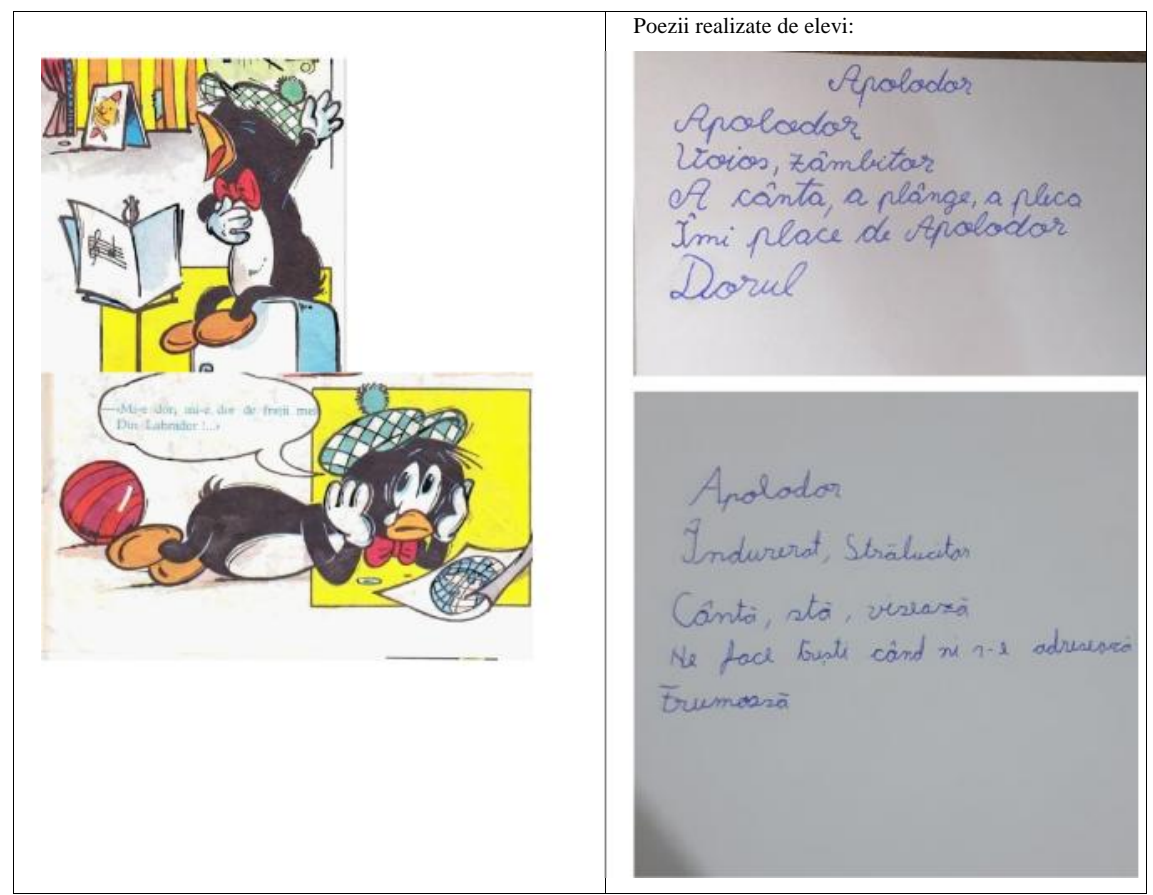

Figura nr. 3. Realizarea unui cvintet

Sursa: Cartea cu Apolodor (Naum, 1988)

În redactarea cvintetului, elevii cu nevoi educa ionale speciale au reuşit să identifice trăsăturile şi ac iunile personajului din imaginile expuse, prezentând dificultă i în exprimarea stării lor fa ă de personajul Apolodor. Unii au reuşit însă să scrie: ,Îmi place de Apolodor.”, ,Ne face trişti când ni se adresează” sau „,Mi-e milă de Apolodor că plânge.” Se poate observa dificultatea cu care elevul deficient îşi exprimă propriile stări şi idei. 
Alteori, am organizat ateliere de crea ie, în care elevii au redactat diverse texte pornind de la imagini sau de la diferite filmule e de anima ie. În vederea dezvoltării competen ei de redactarea a textului scris de diverse tipuri, am folosit jocul educativ ,Zarurile cu poveşti”.

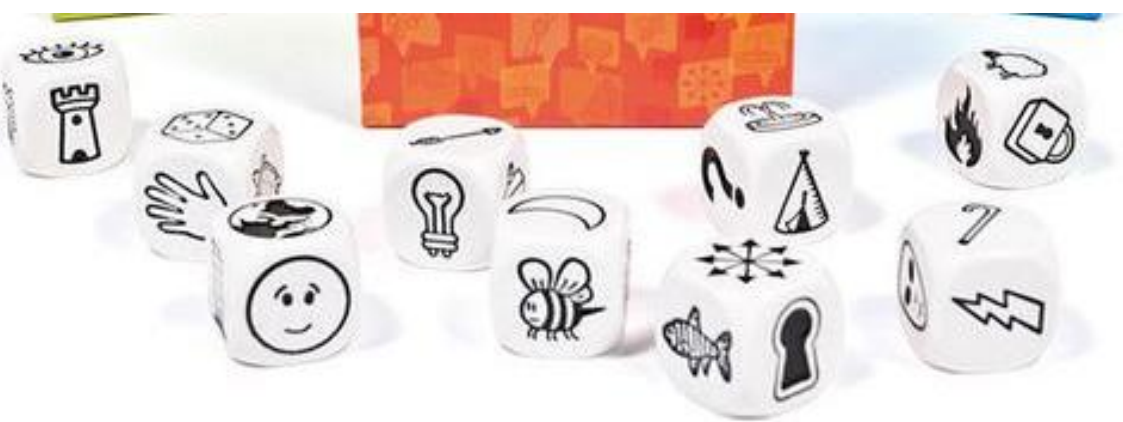

Figura nr. 4. Atelier de crea ie

Sursa: Cuburi de poveste, Joc Rory's Story Cubes

Pornind de la joc, le-am oferit copiilor ocazia de a-şi dovedi îndemânarea, confec ionând din carton cele nouă zaruri. Pentru realizarea sarcinii, i-am împăr it pe copii în trei grupe şi i-am rugat să confec ioneze câte trei cuburi, având de ilustrat pe fe ele acestora diferite obiecte, vie uitoare, emoticoane etc. Fiecare cub trebuia să ilustreze alte elemente, să nu se repete imaginile. Ulterior, pornind de la cuburile realizate, elevii au avut sarcina de a redacta o nara iune, de minimum 120 de cuvinte, folosind ilustra iile de pe fe ele celor nouă zaruri. Elevii cu un nivel mai scăzut de cunoştin e au alcătuit propozi ii scurte. Unii elevi au reuşit să îşi imagineze întâmplări scurte. Am observat că unii elevi nu au respectat succesiunea logică a întâmplărilor.

După cum aminteam în paginile de mai sus, este determinant pentru reuşita învă ării ca elevii cu dizabilită i intelectuale să fie puşi în situa ii de comunicare concrete, care să răspundă nevoilor acestora, deoarece capacitatea lor de exprimare, atât în comunicarea orală, cât şi în cea scrisă, presupune utilizarea unui număr mic de cuvinte, precum şi limite în respectarea normelor gramaticale. De exemplu, am constatat că elevii nu fac acordul între subiect şi predicat, omit predicatul, în unele cazuri, sau că manifestă posibilită i reduse 
de exprimare cu intona ii expresive. Mai ales când citesc, elevii cu dizabilită i intelectuale nu respectă pauzele şi nu pun accentul logic. Citirea este greoaie, cu multe poticniri, cuvintele sunt silabisite. Provoca i să povestească diferite întâmplări din via a personală, elevii cu dizabilită i intelectuale nu reuşesc să îşi organizeze amintirile, se limitează la o relatare superficială. Atunci când sunt întreba i, aceștia răspund monosilabic, cu „Da” sau „Nu”, răspunsurile nu sunt organizate în propozi ii, uneori răspund prin gesturi. În vederea formării competen ei de a dialoga în situa ii din via a cotidiană, i-am pus pe elevi în situa ia de a-şi imagina un scurt dialog între personajele reprezentate în imaginile de mai jos.
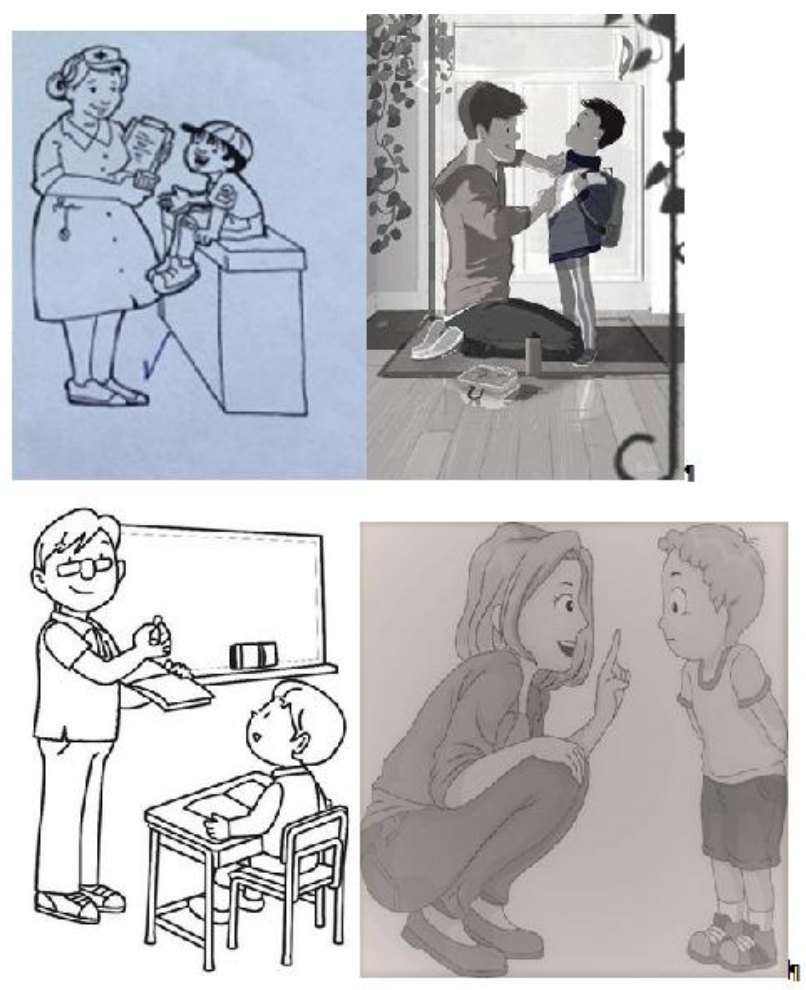

Figura nr. 5. Dialog în situa ii cotidiene 
Elevii au lucrat în perechi, reuşind să asocieze imaginile cu situa iile concrete din via a de zi cu zi. Fiecare pereche a selectat o singură imagine. Pornind de la imagine, elevii au redactat un dialog de minimum şase replici. După redactarea dialogului, elevii au interpretat dialogul în fa a clasei. Am observat faptul că activitatea a generat o stare de bună dispozi ie, elevii au participat activ, reuşind să realizeze cu succes sarcina de lucru. Unii elevi au manifestat o atitudine critică fa ă de interpretarea colegilor.

În practica de la clasă, am constatat că pentru dezvoltarea expresivită ii vorbirii sunt utile scenetele, jocul de rol sau piesele de teatru. De asemenea, elevii mai mari pot fi învă a i să conducă teatrul de păpuşi, la care vor participa ca spectatori elevii mai mici. Un joc de rol interesant a fost realizat plecând de la cartea pentru copii Gruffalo, de Julia Donaldson. Elevii citesc textul pentru a se familiariza cu subiectul şi cu personajele. În continuare, elevii pot viziona anima ia, în vederea sesizării elementelor nonverbale şi paraverbale utilizate în completarea comunicării verbale. Filmul de anima ie reprezintă un model concret pentru modul în care elevii au de interpretat fiecare personaj. După această etapă, pe grupe de câte şase elevi, se trece la interpretarea textului. Fiecare dintre cei şase elevi va primi un rol, respectiv rolul naratorului/ al povestitorului, cel al şoricelului, al lui Gruffalo, rolul vulpii, al bufni ei şi cel al şarpelui. Pentru a-i motiva, le-am propus să înregistrăm interpretarea lor, s-o putem asculta şi comenta împreună (vezi figura nr. 6 de pe pagina următoare). În acest context de lucru, am constatat beneficii privind modul în care copiii îşi dezvoltă spiritul critic, devenind mai interesa i fa ă de exprimarea corectă.

În contextul dezvoltării competen elor de comunicare ale elevilor cu dizabilită i intelectuale, nu pot fi neglijate nici mijloacele comunicării nonverbale, respectiv mimica, pozi ia corpului, gesturile. În acest scop, am organizat jocuri în care un elev imită aumite stări: veselia, uimirea, supărarea, triste ea, iar ceilal i elevi traduc în cuvinte ce au observat. Am constatat că jocul de rol activează elevii prin implicarea lor într-o activitate nouă, interesantă, iar interac iunea dintre participan i le permite elevilor să-şi dezvolte autocontrolul, în ceea ce priveşte comportamentul. 


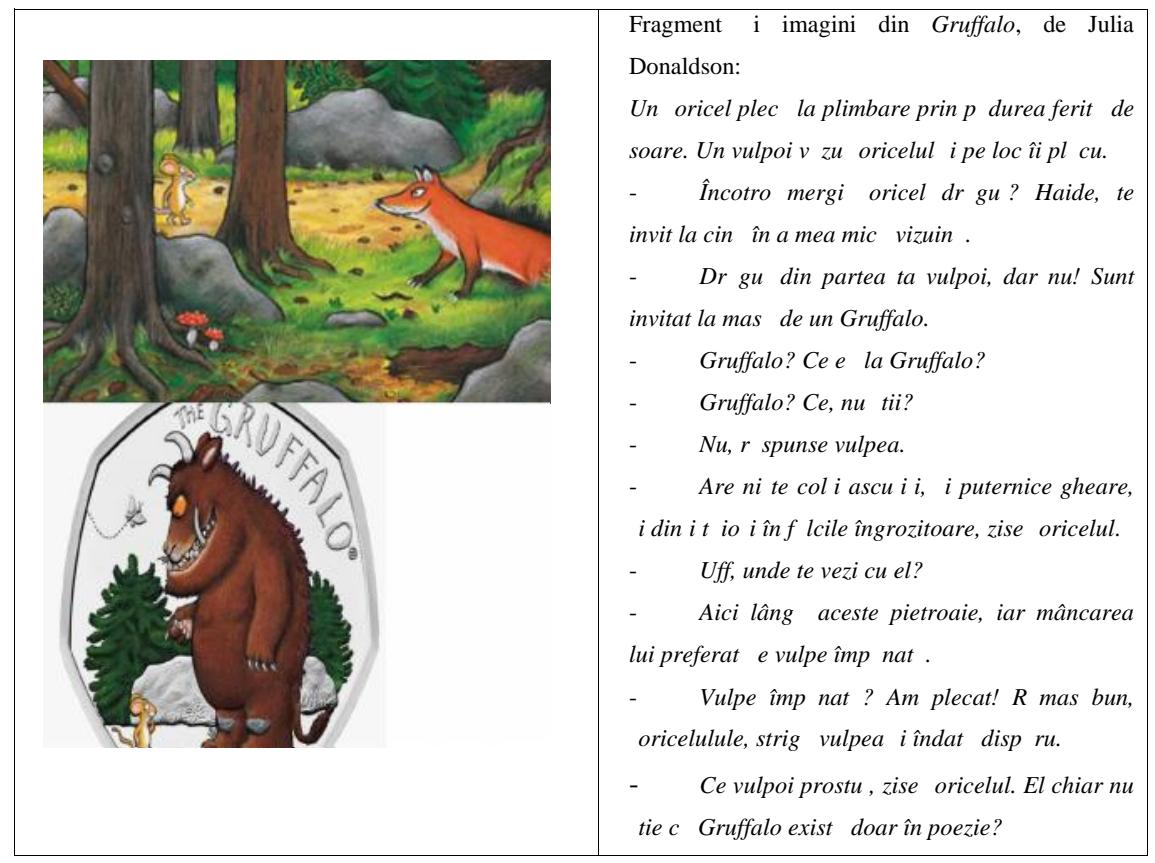

Figura nr. 6. Interpretarea unor roluri

Sursa: Fragment şi imagini din Gruffalo, Julia Donaldson

\section{Concluzii}

În situa ia în care profesorul se adresează copiilor cu dizabilită i intelectuale, devine mult mai evident faptul că reuşita lui este determinată de modul în care pune accentul pe dimensiunea formativă şi creativă a actului didactic. Este mult mai evident, în egală măsură, faptul că profesorul este pus în situa ia de a reflecta şi de a evita clişeele didactice, deoarece acestea limitează nu doar creativitatea elevilor, ci şi rezultatele învă ării. Fără această creativitate şi flexibilitate a profesorului, elevii nu vor putea să creeze idei noi, originale. Elevii prosperă dacă au libertatea de a se manifesta, trebuie să li se creeze un climat al posibilită ilor, activită ile de învă are să fie centrate pe interesele lor, pe dezvoltarea de competen e şi pe motivarea intrinsecă a acestora. Dacă acest aspect poate reprezenta o aser iune generală în raport cu anumi i copii, în situa ia copiilor cu dizabilită i intelectuale, aplicarea acestor 
principii devine condi ie de reuşită. Prin urmare, competen a de comunicare a elevilor cu dizabilită i intelectuale poate fi dezvoltată doar prin competen a profesională a cadrelor didactice, prin curriculum personalizat şi prin strategii didactice eficiente. Atât copiii cu dizabilită i intelectuale, cât şi cei normal dezvolta i înva ă mai uşor dacă profesorul ine cont de ritmurile lor de învă are şi le propune trasee diferen iate. De aceea, organizarea unei educa ii incluzive pentru elevii cu nevoi speciale de învă are aduce mai multe beneficii, în sensul că un profesor este provocat să găsească solu ii adaptate nevoilor copiilor şi că are posibilitatea de a constata mult mai clar cât de eficiente sunt, de fapt, strategiile de predare - învă are alese.

\section{Referin e}

- Berner, R.S. (2018). Hoinari prin anotimpuri. Editura Casa.

- Blaga, L. (2012). Hronicul şi cântectul vârstelor. Editura Humanitas.

- Borchin, M.-I. (2005). Vademecum în lingvistică. Editura Excelsior Art.

- Donaldson, J. (2014). Gruffalo. Editura Macmillan.

- Jakobson, R. (1964). Lingvistică şi poetică. În T. Constantinescu (Ed.), Probleme de stilistică. Editura Ştiin ifică.

- Mircea, Şt. (2006). Lexicon pedagogic. Editura Aramis.

- Naum, G. (1998). Cartea cu Apolodor. Editura Ion Creangă.

- Naum, G. (2016). Cartea cu Apolodor. Editura Arthur.

- Organiza ia Mondială a Sănătă ii (2004). Clasificarea interna ională a func ionării, dizabilită ii şi sănătă ii. MarLink. http://anpd.gov.ro/web/wpcontent/uploads/2016/06/Clasificarea-internationala-a-functionarii-dizabilitatii-sisanatatii-CIF-CT-verrsiunea-pentru-copii-si-tineri-2012.pdf

- Roşca, M. (1967). Psihologia deficien ilor mintali. Editura Didactică şi Pedagogică.

- Saint- Exupery, A. (2019). Micul prin . Editura Arthur. 
The online version of this article can be found at: http://revped.ise.ro/category/2020-en/

\section{(CC) $\mathbb{B Y - N C - S A}$}

This work is licensed under the Creative Commons Attribution-NonCommercial-ShareAlike 4.0 International License.

To view a copy of this license, visit http://creativecommons.org/licenses/by-nc-sa/4.0/ or send a letter to Creative Commons,

PO Box 1866, Mountain View, CA 94042, USA.
Versiunea online a acestui articol poate fi găsită la: http://revped.ise.ro/category/2020-ro/

\section{(cC) DY-NC-SA}

Această lucrare este licen iată sub Creative Commons Attribution-NonCommercial-ShareAlike 4.0 International License.

Pentru a vedea o copie a acestei licen e, vizita $i$ http://creativecommons.org/licenses/by-nc-sa/4.0/ sau trimite i o scrisoare către Creative Commons, PO Box 1866, Mountain View, CA 94042, SUA. 